\title{
ISOLASI DAN AMPLIFIKASI DNA KELADI TIKUS (Thyponium flagelliform) UNTUK IDENTIFIKASI KERAGAMAN GENETIK
}

\section{Isolation and amplification of Keladi tikus (Thyponium flagelliform) DNA for identification of genetic variation}

\author{
Mohamad Fazri Hikmatyar $^{1}$, Juwartina Ida Royani ${ }^{2, \star}$, Dasumiati $^{1}$ \\ ${ }^{1}$ Jurusan Bioteknologi, Fakultas Teknologi dan Sains, \\ Universitas Islam Negeri Syarif Hidayatullah, Ciputat, Tangerang Selatan \\ ${ }^{2}$ Balai Pengkajian Bioteknologi BPPT, Gedung 630 Kawasan PUSPIPTEK, \\ Setu, Tangerang Selatan, Banten 15314 \\ *E-mail: juwartina.ida@bppt.go.id
}

\begin{abstract}
Keladi tikus (Typhonium flagelliforme) is one of considerable potential medicinal plants, especially as anticancer herbal medicine. In Indonesia, this plant grows throughout the island of Java, in part of Kalimantan, Sumatra and Papua. The development of Keladi tikus plants to provide raw material to meet public demand is constrained with the quality of the plants that is not standardized yet. DNA marker technique has been widely used for identification of standardization and diversity of varieties. The aims of this research were to isolate DNA from 17 accessions of Keladi tikus from various regions in Indonesia and to amplify the DNA using ISSR primers. The results obtained were 17 accessions of Keladi tikus that had been isolated using the modified CTAB method. Amplifications were done by using SBLT2 and SBLT8 primers that facilitated the appearance of the polymorphism bands on the 17 accessions of Keladi tikus. Thus, SBLT2 and SBLT8 primers can be used to identify genetic variations of Keladi Tikus.
\end{abstract}

Keywords: Typonium flagelliforme, Keladi tikus, ISSR, medicinal plant, amplification

\begin{abstract}
ABSTRAK
Keladi tikus (Typonium flagelliforme) merupakan salah satu tanaman obat yang cukup potensial khususnya sebagai obat herbal antikanker. Tanaman ini di Indonesia tersebar di sepanjang Pulau Jawa, sebagian Kalimantan, Sumatera dan Papua. Pengembangan tanaman keladi tikus untuk memenuhi bahan baku kebutuhan masyarakat saat ini terkendala pada mutu tanaman tersebut yang belum terstandar. Teknik penanda DNA telah banyak digunakan untuk standarisasi dan identifikasi keragaman varietas. Tujuan dari penelitian ini adalah untuk mengisolasi DNA dari 17 aksesi Keladi tikus dari berbagai daerah di Indonesia dan mengamplifikasi DNA tersebut dengan primer ISSR. Hasil penelitian menunjukkan bahwa 17 aksesi keladi tikus telah dapat diisolasi dengan menggunakan metode CTAB yang dimodifikasi. Amplifikasi dilakukan dengan primer SBLT2 dan SBLT8 yang mampu memunculkan pita-pita polimorfisme pada ke 17 aksesi Keladi tikus. Primer SBLT2 dan SBLT8 dapat digunakan untuk identifikasi variasi genetic Keladi tikus.
\end{abstract}

Kata Kunci: Keladi tikus, Typonium flagelliforme, ISSR, tanaman obat, amplifikasi 


\section{PENDAHULUAN}

Keladi tikus (Typonium flagelliforme) merupakan tanaman yang termasuk golongan rerumputan yang bentuknya menyerupai talas. Tanaman ini di Indonesia tersebar di sepanjang Pulau Jawa, sebagian Kalimantan, Sumatera dan Papua (Harfia 2006). Keladi tikus merupakan salah satu tanaman obat yang potensial khususnya sebagai obat herbal antikanker, tetapi tanaman ini tergolong pendatang baru dalam khasanah pengobatan herbal (Sudewo 2004). Analisis fitokimia terhadap Keladi tikus menunjukkan bahwa terdapat kandungan senyawa alkaloid, saponin, steroid, glikosida, antioksidan (Syahid 2007) fitol dan asam lemak (fatty acid) (Choon et al. 2008). Senyawa aktif tersebut memiliki sifat antineoplastik atau antikanker yang mampu mencegah, membunuh serta menghambat pertumbuhan dan penyebaran sel kanker.

Pengembangan tanaman keladi tikus untuk memenuhi kebutuhan masyarakat saat ini terkendala pada mutu tanaman tersebut yang belum terstandar. Hal ini disebabkan penyediaan tanaman keladi tikus masih dilakukan dengan teknik yang konvensional. Salah satu solusi untuk mengatasi masalah ini ialah dengan mengetahui informasi keragaman tanaman keladi tikus.

Penelitian tanaman keladi tikus dengan tujuan mengatasi masalah ini telah dilakukan. Salah satunya ialah penelitian yang dilakukan oleh Syahid (2008) mengenai keragaman morfologi, pertumbuhan, mutu, produksi dan fotokimia pada tanaman keladi tikus. Hasil penelitian menunjukkan bahwa penampakan secara morfologi tidak ada perbedaan sama sekali, namun untuk karakter mutu dan fotokimia sangat berbeda.

Perkembangan identifikasi keragaman genetik tanaman secara molekuler berbasis Polymerase Chains Reaction (PCR) menjadi solusi untuk mendeteksi dan menentukan keaslian bahan baku tanaman obat. Teknik penanda DNA telah banyak digunakan untuk mengetahui keaslian spesies-spesies penting dari tanaman obat (Joshi et al. 2004). Teknik ini dapat digunakan untuk penentuan sidik jari DNA (DNA fingerprinting) dari tanaman obat dan identifikasi keragaman varietas. Penanda
DNA sangat akurat karena dapat memberikan informasi polimorphisme, sebagai komposisi genetik yang unik pada masing-masing spesies, yang tidak tergantung pada umur dan kondisi fisiologi seperti faktor lingkungan (Joshi et al. 2004). Teknik penanda DNA ini juga telah banyak digunakan untuk mengetahui keaslian spesies-spesies penting dari tanaman obat (Joshi et al. 2004). Peneliti dari Cina telah mengaplikasikan penanda DNA secara ekstensif untuk karakterisasi tanaman dari tanaman obat Cina.

Salah satu penanda DNA yang banyak digunakan saat ini adalah penanda Inter Simple Sequences Repeats (ISSR). Penanda ISSR merupakan salah satu penanda dengan motif urutan berulang yang mengamplifikasi urutan DNA pada inter-SSR bagian flanked genom secara berlawanan pada area yang dekat dengan urutan berulang (Zietkiewicz et al. 1994). Penanda ISSR potensial digunakan untuk mendeteksi keragaman genetik tanaman baik pada tingkat intraspesies maupun pada tingkat interspesies antara lain keragaman genetik gandum di Cina Barat (Hou et al. 2005) dan jarak pagar di India dan Meksiko (Basha dan Sujatha 2007).

Tujuan dari penelitian ini adalah untuk mengisolasi DNA dari 17 aksesi Keladi tikus dari berbagai daerah di Indonesia dan mengamplifikasi DNA tersebut dengan primer ISSR.

\section{BAHAN DAN METODE}

Bahan yang digunakan adalah daun tanaman keladi tikus dari 17 aksesi yang berasal dari beberapa daerah di Indonesia Tabel 1.

\section{Isolasi DNA 17 aksesi}

Isolasi DNA tanaman keladi tikus dilakukan dengan menggunakan metode Cetyl Trimethyl Ammonium Bromide (CTAB) yang telah di modifikasi (Royani 2012). Sebanyak 17 aksesi tanaman keladi tikus diisolasi DNA nya dari daun muda. Daun dibuang tulang daunnya dan ditimbang sebanyak 200 mg kemudian digunting hingga berukuran kecil dan dimasukkan ke dalam lumpang. Daun ditambahkan larutan Poly Vinyl Pyrolidone (PVP) 1\% sebanyak $100 \mu \mathrm{L}$, dapar $\mathrm{CTAB}$ suhu $60^{\circ} \mathrm{C}$ sebanyak 
Tabel 1. Aksesi 17 Keladi tikus dari berbagai daerah di Indonesia

\begin{tabular}{cc}
\hline Aksesi & Asal/lokasi \\
\hline 1 & Petulu Agung Bali \\
2 & Bogor Jawa Barat \\
3 & Suka Raja Baru Ogan Ilir, Sumatera selatan \\
4 & Solok Sumatera Barat \\
5 & Balikpapan \\
6 & BPTO I Tawangmangu \\
7 & Bank Mandiri Jogjakarta \\
8 & Singa Raja, Bali \\
9 & Menoreh, Jogjakarta \\
10 & Sukabumi Jawa Barat \\
11 & Salatiga Kabupaten Sengon (I) \\
12 & Timbangan Indralaya, Sumatera Selatan \\
13 & Ny Mener Ungaran Semarang \\
14 & Tanjung Bungkak Denpasar Bali \\
15 & Indmira Jogjakarta \\
16 & Matesih, Jogjakarta \\
17 & Merapi Farm Jogjakarta \\
\hline
\end{tabular}

$250 \mu \mathrm{L}$ dan $2 \%$ merkaptoetanol suhu $60^{\circ} \mathrm{C}$ sebanyak $100 \mu \mathrm{L}$. Ekstrak daun yang telah digerus halus dimasukkan ke tabung mikro dengan menggunakan spatula dan ditambahkan dapar CTAB sebanyak $250 \mu \mathrm{L}$ ke dalam tabung mikro.

Sampel dinkubasi dalam water bath dengan suhu $60^{\circ} \mathrm{C}$ selama 30 menit dan setiap 10 menit sampel dihomogenkan dengan vortex. Sampel diangkat dan ditambahkan larutan Chloroform Isoamyl Alcohol (CIAA) sebanyak $500 \mu \mathrm{L}$ dan dibolak-balik \pm 15 menit. Kemudian sampel disentrifugasi pada kecepatan 800 rpm selama 10 menit. Larutan supernatan yang terbentuk pada bagian atas sampel dipindahkan ke tabung mikro yang baru dan dihitung volume supernatan yang dipindahkan. $\mathrm{NaCl} 5 \mathrm{M}$ sebanyak $250 \mu \mathrm{L}$ ditambahkan ke dalam sampel, lalu dikocok perlahan hingga tercampur. Larutan isopropanol dingin sebanyak $0,6 x$ volume total sampel (supernatan dan $\mathrm{NaCl}$ ) ditambahkan ke tabung mikro. Tabung mikro yang berisi sampel dibolak-balik perlahanlahan hingga larutan tercampur rata.

Sampel diinkubasi pada suhu ruang selama 15 menit, lalu disentrifugasi dengan kecepatan $10.000 \mathrm{rpm}$ selama 10 menit. Supernatan yang terbentuk dibuang dan sebanyak $200 \mu \mathrm{L}$ ethanol $80 \%$ ditambahkan. Larutan etanol dibuang, pelet DNA yang didapat dikeringkan dengan cara membalikkan tabung mikro di atas kertas tissu. Etanol yang masih tersisa di dalam tabung mikro dikeringkan dengan kertas tissu yang telah digunting membentuk segitiga lancip. Pelet DNA ditambahkan Tris $\mathrm{HCl}$ :EDTA (TE) pH 8 sebanyak $30 \mu \mathrm{L}$ dan dihomogenkan. DNA hasil isolasi yang didapat disimpan di lemari pendingin dengan suhu $-20^{\circ} \mathrm{C}$ sampai akan digunakan.

\section{Pengukuran kualitatif dan kuantitatif DNA \\ Pengukuran DNA secara kualitatif pada 17 aksesi tanaman Keladi tikus dilakukan dengan menggunakan elektroforesis gel agarosa dan diperiksa di bawah UV transilluminator. Sedangkan untuk pengukuran DNA secara kuantitatif dilakukan dengan menggunakan nanodrop spektrofotometri dengan perbandingan absorbansi pada 260/280.}

\section{Amplifikasi DNA dengan penanda ISSR}

Amplifikasi DNA dari 17 aksesi tanaman Keladi tikus dilakukan dengan menggunakan primer ISSR yaitu primer SBLT2 (AG)8T dan SBLT8 (CT)8G (Royani 2012) dengan menggunakan mesin Polymerase Chain Reaction (PCR). Amplifikasi dilakukan pada kondisi: denaturasi awal 5 menit pada $94^{\circ} \mathrm{C}$, denaturasi selama 1 menit pada $94^{\circ} \mathrm{C}$, annealing primer dilakukan selama 45 detik dengan suhu $52^{\circ} \mathrm{C}$. Primer yang digunakan adalah 2 primer ISSR yaitu primer SBLT2 dan primer SBLT8. Tahap berikutnya ialah elongasi pada suhu $72^{\circ} \mathrm{C}$ selama 2 menit dilanjutkan dengan tahap elongasi akhir pada suhu $72^{\circ} \mathrm{C}$ selama 5 menit. Hasil produk PCR diperiksa dengan elektroforesis dengan 1,5\% (w/v) gel agarosa. Hasil elektroforesis diamati di bawah UV transiluminator untuk mengetahui pita yang terbentuk.

\section{HASIL DAN PEMBAHASAN}

Isolasi DNA tanaman keladi tikus pada penelitian ini dilakukan dengan metode CTAB yang dimodifikasi (Royani 2012). Penggunaan daun yang masih muda disebabkan daun muda memiliki tekstur lunak dan sedikit mengandung serat sehingga mudah dalam proses penggerusan dan pemurnian DNA (Ardiana 2009). Uji DNA secara kualitatif untuk mengetahui 
kualitas DNA yang diisolasi dilakukan dengan elektroforesis gel agarosa 1,5\% (w/v) menggunakan pewarna SYBR safe ${ }^{\mathrm{TM}}$. Elektroforesis memiliki prinsip kerja memanfaatkan muatan listrik yang ada pada DNA yang bermuatan negatif. DNA yang dialiri arus listrik dari satu kutub ke kutub yang berlawanan muatannya, maka molekul tersebut akan bergerak dari kutub negatif ke kutub positif (Yuwono 2005). Hasil uji DNA yang baik dengan elektroforesis ditunjukkan dengan pita DNA yang tebal dan tampak sedikit atau tidak ada smear jika divisualisasikan di atas sinar UV (Sauer et al. 1998).

Elektroforegram hasil isolasi DNA 17 aksesi Keladi tikus (Gambar 1) menunjukkan hampir seluruh DNA aksesi Keladi tikus berhasil diisolasi. DNA yang berhasil diisolasi ditunjukkan dengan pita DNA tegas dan jelas yang berpendar di atas gel pada saat disinari sinar ultraviolet. Smear yang nampak di bawah dekat pita DNA menunjukkan bahwa DNA yang diisolasi tidak utuh atau patah-patah, sedangkan penampakan smear yang terletak pada bagian terbawah setiap lajur menunjukkan adanya kontaminasi berupa RNA. Menurut Sauer et al. (1998) smear atau bayangan yang muncul pada setiap lajur dan terletak paling bawah menunjukkan bahwa DNA terkontaminasi RNA.

Elektroforegram hasil isolasi DNA di atas menunjukkan bahwa hampir seluruh sampel DNA memiliki kualitas baik, namun ada 2 sampel DNA asal aksesi Balikpapan dan Sukabumi yang memiliki kualitas kurang baik. Kedua sampel DNA tersebut tidak tampak adanya pita yang tegas dan jelas pada gel agarosa. Hal ini dapat disebabkan oleh kedua sampel DNA aksesi tersebut memiliki kemurnian dan konsentrasi yang rendah.

Uji keberhasilan DNA yang kedua ialah uji kuantitatif dengan menggunakan nano drop spektrofotometri. Prinsip kerja nano drop spektrofotometri ialah DNA murni mampu menyerap cahaya ultraviolet karena adanya basa purin dan pirimidin (Fatchiyah et al. 2011). Hasil uji nano drop ialah berupa nilai kemurnian DNA pada Å260/Å280 dan nilai konsentrasi DNA. DNA berkualitas baik berdasarkan uji nano drop memiliki kemurnian 1,8-2,0 (Fatchiyah et al. 2011; Sambrook et al. 2001) dan konsentrasi di atas $100 \mathrm{ng} / \mu \mathrm{L}$.
Sebagian besar DNA aksesi keladi tikus memiliki kemurnian yang baik (Tabel 2) dengan kemurnian berkisar antara 1,8-2,0. Hanya ada 4 sampel DNA yang memiliki kemurnian kurang baik. Aksesi dengan kemurnian kurang baik yaitu aksesi dari Balikpapan, Bogor, Solok dan Sukabumi. DNA aksesi Balikpapan memiliki nilai kemurnian di bawah 1,8. Nilai kemurnian DNA di bawah 1,8 mengindikasikan pada DNA hasil ekstraksi masih terdapat kontaminan berupa senyawa protein. Kontaminasi berupa senyawa protein pada DNA dapat disebabkan oleh tidak adanya penambahan enzim protease pada protokol isolasi DNA (Kartini 2012).

DNA aksesi Bogor, Solok dan Sukabumi memiliki nilai kemurnian di atas 2,0. Menurut Fatchiyah et al. (2011) nilai kemurnian DNA di atas 2,0 mengindikasikan masih terdapat kontaminan berupa RNA. Hal ini mungkin disebabkan pada penelitian ini tidak dilakukan penambahan ribonuklease. Menurut Kartini (2012) kontaminan berupa RNA dapat diatasi dengan penambahan ribonuklease. Penambahan ribonuklease pada penelitian ini tidak dilakukan karena protokol penambahan enzim melalui banyak tahapan-tahapan yang sering kali dapat mengurangi konsentrasi DNA secara signifikan.

Tabel 2. Aksesi Keladi tikus dan hasil pengukuran kualitatif dan kuantitatif DNA dari 17 aksesi

\begin{tabular}{clcr}
\hline Aksesi & Lokasi Asal & $\begin{array}{c}\text { Rata-rata } \\
\text { Kemur- } \\
\text { nian }\end{array}$ & $\begin{array}{c}\text { Rata-rata } \\
\text { Konsen- } \\
\text { trasi }\end{array}$ \\
\hline 1 & Petulu Agung Bali & 1,82 & 132,69 \\
2 & Bogor Jawa Barat & 2,02 & 3302,56 \\
3 & Suka Raja Baru Ogan llir, Sumatera Selatan & 1,88 & 975,47 \\
4 & Solok Sumatera Barat & 2,13 & 2762,21 \\
5 & Balikpapan & 1,39 & 4478,66 \\
6 & BPTO I Tawangmangu & 1,89 & 1057,53 \\
7 & Bank Mandiri Jogjakarta & 1,84 & 4011,11 \\
8 & Singa Raja, Bali & 1,93 & 3667,60 \\
9 & Menoreh, Jogjakarta & 1,91 & 53,53 \\
10 & Sukabumi Jawa Barat & 2,15 & 1028,49 \\
11 & Salatiga Kabupaten Sengon (I) & 1,93 & 3878,64 \\
12 & Timbangan Indralaya, Sumatera Selatan & 1,87 & 960,79 \\
13 & Ny Mener Ungaran Semarang & 1,84 & 3995,21 \\
14 & Tanjung Bungkak Denpasar Bali & 1,95 & 72,88 \\
15 & Indmira Jogjakarta & 1,88 & 1262,65 \\
16 & Matesih, Jogjakarta & 2,00 & 1679,70 \\
17 & Merapi Farm Jogjakarta & 1,85 & 1951,33 \\
\hline & & & \\
\hline
\end{tabular}




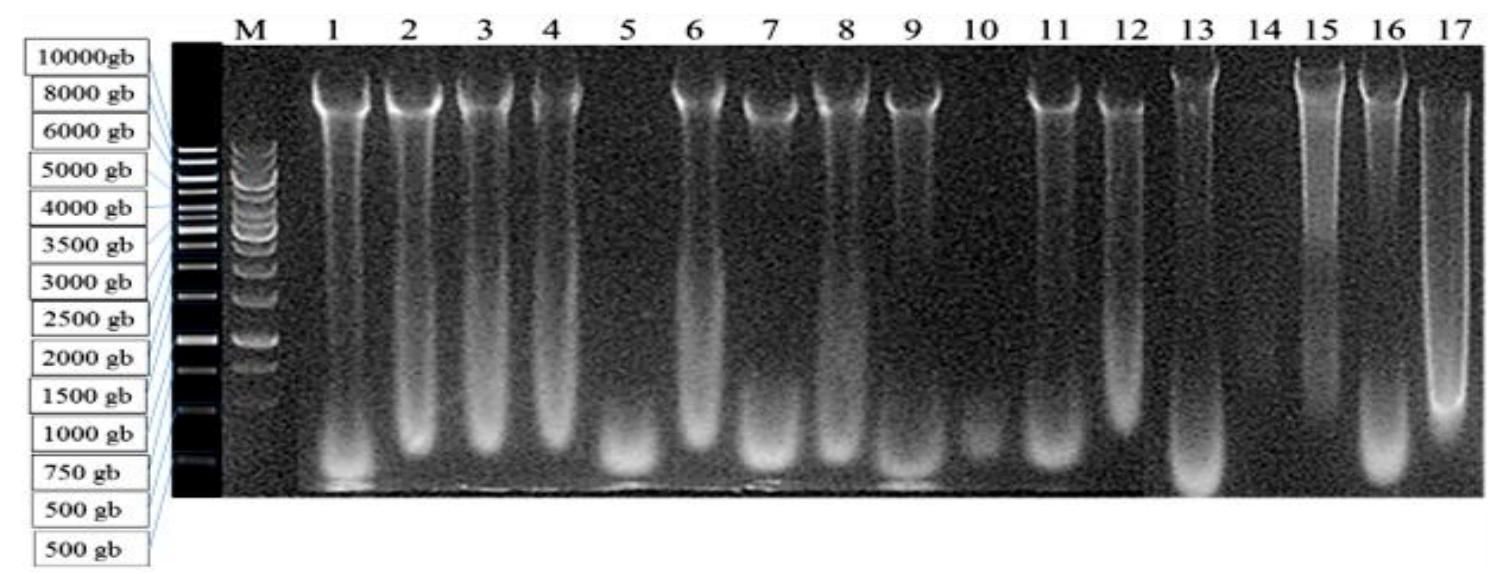

Gambar 1. Elektroforegram hasil isolasi DNA dari 17 aksesi Keladi tikus. M: marker 1 kb, 1-17: aksesi keladi tikus

Selain melihat kemurnian DNA dari uji nano drop juga dapat dilihat konsentrasi DNA hasil isolasi. Sebagian besar sampel DNA yang diisolasi memiliki konsentrasi yang sangat tinggi, hanya ada 2 sampel DNA (aksesi Menoreh dan Tanjung Bungkak) yang memiliki konsentrasi yang sangat rendah dengan nilai berturut-turut $53,53 \mathrm{ng} / \mu \mathrm{L}$ dan $72,88 \mathrm{ng} / \mu \mathrm{L}$.

Hasil uji DNA secara kualitatif dan kuantitatif sebagian besar menunjukkan bahwa DNA yang diisolasi dengan metode modifikasi CTAB pada penelitian ini memiliki beberapa kelemahan dan kelebihan. Kelebihan metode CTAB ini adalah mampu mengurangi senyawa polisakarida dan senyawa metabolit sekunder. Hal ini sangat terlihat dari data kemurnian DNA aksesi keladi tikus (Tabel 2) yang menunjukkan bahwa sebagian besar memiliki nilai yang baik, yaitu berkisar antara 1,8-2,0. Hal ini sesuai dengan hasil penelitian Khanuja et al. (1999) bahwa isolasi DNA menggunakan metode CTAB dimodifikasi dengan bahan tanaman penghasil senyawa metabolit sekunder yang tinggi mampu menghasilkan kualitas DNA yang baik. Kualitas DNA yang baik dibuktikan kembali dengan amplifikasi yang menghasilkan pola pita yang sangat jelas.

Masalah yang dihadapi pada isolasi DNA pada tanaman Keladi tikus ialah senyawa metabolit sekunder yang sering kali mengurangi kemurnian DNA. Senyawa polisakarida merupakan salah satu senyawa yang dapat mengganggu kemurnian DNA. Menurut Khanuja et al. (1999) polisakarida dapat diatasi dengan penambahan $\mathrm{NaCl}$ dengan konsentrasi yang tinggi. Fang et al.
(1992) dan Tel-zur et al. (1999) menambahkan bahwa penambahan $\mathrm{NaCl}$ dengan konsentrasi di atas $1 \mathrm{M}$ dapat meningkatkan kelarutan polisakarida sehingga lebih mudah untuk dihilangkan dari DNA. Berdasarkan hal tersebut maka pada protokol isolasi DNA ditambahkan $\mathrm{NaCl}$ dengan konsentrasi $5 \mathrm{M}$.

Senyawa lain dari tanaman Keladi tikus yang dapat menghambat kemurnian DNA ialah polifenol dan protein. Polifenol dapat diatasi dengan PVPP dan merkaptoetanol yang terdapat pada komposisi dapar ekstraksi (Khanuja et al. 1999). Kontaminasi protein dapat diatasi dengan Kloroform isoamilalkohol. Kloroform isoamilalkohol mampu menghilangkan senyawa protein tanpa mendenaturasi DNA karena DNA merupakan senyawa hidrofilik yang tidak larut dalam pelarut organik. Kemampuan deproteinasi kloroform didasarkan atas kemampuan kloroform untuk mendenaturasi rantai polipeptida yang sebagian masuk atau termobilisasi pada interfase air-klorofom. Isoamilalkohol memiliki fungsi sebagai emulsifier, yaitu meningkatkan luas tegangan permukaan dari air-kloroform agar proses deproteinasi semakin maksimal (Agrawal 2008).

DNA dimurnikan kembali dengan proses presipitasi. Presipitasi bertujuan untuk mengendapkan DNA dan memisahkannya dari senyawa garam-garam mineral dan sisa-sisa CTAB. Senyawasenyawa tersebut dapat mengganggu proses enzimatis pada tahap PCR (Weising et al. 1995). Proses presipitasi DNA dilakukan dua kali dengan menggunakan larutan isopropanol dingin dan etanol $80 \%$. 

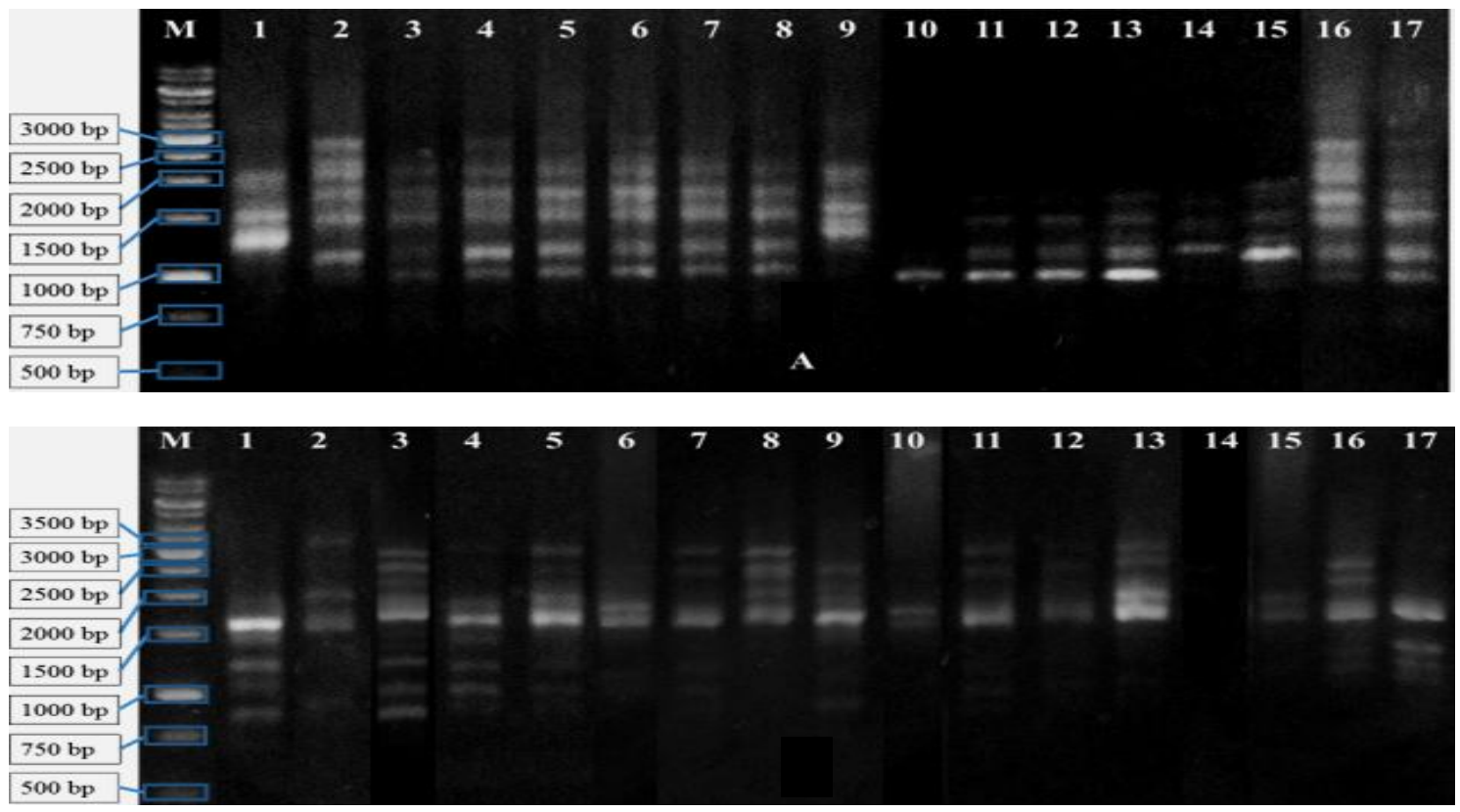

Gambar 2. Elektroforegram hasil amplifikasi DNA 17 aksesi tanaman Keladi tikus menggunakan primer SBLT2 (atas) dan SBLT8 (bawah), M: Marker 1 kb, 1-17: aksesi keladi tikus)

Tahapan presipitasi ini pada prinsipnya ialah menurunkan kelarutan DNA dalam air. Isopropanol dingin dapat mengurangi aktivitas molekul air dan mampu menghilangkan molekul air dalam larutan DNA sehingga DNA dapat terpresipitasi (Surzycki 2000). Residuresidu garam yang terlibat dalam proses ekstraksi bersifat kurang larut dalam isopropanol. Residu garam tersebut dapat terpresipitasi bersama DNA, oleh sebab itu dibutuhkan pemurnian kembali menggunakan etanol $80 \%$ (Ausubel et al. 2003).

Berdasarkan hasil uji kualitatif dan uji kuantitatif DNA menunjukkan bahwa tidak semua sampel DNA memiliki kualitas dan kuantitas yang baik, namun sampel DNA ini tetap dilanjutkan ke proses amplifikasi untuk mengetahui DNA yang diisolasi dapat diperbanyak dan dapat digunakan pada penelitian selanjutnya. Padmadi (2009) menyatakan bahwa sampel DNA yang digunakan pada analisis PCR khususnya dalam penanda yang dominan tidak harus merupakan DNA murni. Hal ini sesuai dengan hasil penelitian Kartini (2012) bahwa DNA dengan kemurnian 1,12-1,64 juga mampu teramplifikasi dan menghasilkan pola pita amplifikasi yang jelas.

Amplifikasi DNA Keladi tikus dengan menggunakan primer ISSR dilakukan untuk membuktikan bahwa DNA yang diisolasi masih mampu untuk diperbanyak dan dapat digunakan untuk penelitian selanjutnya. Hasil amplifikasi DNA 17 aksesi tanaman Keladi tikus dapat dilihat pada Gambar 2. Semua DNA dari 17 aksesi Keladi tikus dapat teramplifikasi pada pemakaian primer SBLT2. Pada pemakaian primer SBLT8, hanya 1 aksesi yaitu aksesi Tanjung Bungkak Denpasar Bali tidak dapat teramplifikasi. Hal ini dapat dilihat dengan tidak adanya pita pada aksesi tersebut meskipun sudah diulang beberapa kali.

Menurut Wang et al. (2009), pita DNA hanya akan teramplifikasi bila urutan DNA pada urutan primer cocok dengan urutan basa pada bagian inter mikrosatelit genom tanaman sampel. Sedangkan menurut Tingey et al. (1994) keberhasilan amplifikasi ditentukan oleh ada atau tidaknya urutan DNA yang komplemen atau homolog dengan urutan pada primer. Ditambahkan oleh Weeden et al. (1992) bahwa keberhasilan primer dalam mengamplifikasi dan menghasilkan pita polimorfik juga ditentukan oleh ada atau tidak adanya serta adanya distribusi situs pengenalan annealing primer pada template DNA.

Pada penelitian ini pita-pita yang terbentuk dari hasil amplifikasi juga terlihat jelas pada pemakaian primer SBLT2 dan SBLT8 dan menunjukkan pita-pita polimorfisme yang dapat digunakan untuk penelitian keragaman genetik tanaman selanjutnya. 


\section{KESIMPULAN}

Ke-17 aksesi tanaman Keladi tikus telah berhasil di isolasi DNA nya dengan menggunakan metode modifikasi CTAB dan berhasil diamplifikasi dengan primer SBLT 2 dan SBLT 8. Hasil penelitian ini dapat dilanjutkan pada penelitian selanjutnya untuk mengetahui keragaman genetik tanaman Keladi tikus.

\section{DAFTAR PUSTAKA}

Agrawal S (2008) Techniques in Molecular Biology. International Book And Distrubuting Co. India

Ardiana DW (2009) Teknik isolasi DNA genom tanaman papaya dan jeruk dengan menggunakan modifikasi bufer CTAB. Bul Teknik Pertanian 14:12-16

Ausubel FM, Brent R, Kingston RE, Moore DD, Seidman JG, Smith JA, Struhl K (2003) Current Protocols in Molecular Biology Vol 3. John Wiley and Sons. New York

Choon SL, Rosemal HMH, Nair NK, Majid MIA, Mansor SM, Navaratnam V, (2008) Typhonium flagelliforme inhibits cancer cell growth in vitro and induces apoptosis: An evaluation by the bioactivity guided approach. J Ethnopharm 118:14-20

Faatih M (2009) Isolasi dan Digesti DNA Kromosom. J Penelitian Sains Teknol:61-67

Fang DQ, Roose ML, Krueger RR, Federici CT (1997) Fingerprinting of trifoliate orange germ plasm accessions with isozymes, RFLPs and inter-simple sequence repeat marker. Theor Appl Genet 95:211-219

Fatchiyah A, Widyarti LE, Rahayu S (2011) Biologi Molekular Prinsip Dasar Analisis. Erlangga. Malang

Harfia M (2006) Uji Aktivitas Ekstrak Etanol $50 \%$ Umbi Keladi Tikus (Typhonium flagelliforme (Lood) BI) terhadap Sel Kanker Payudara (MCF-7 Cell line) secara In-Vitro. Puslitbang Biomedis dan Farmasi, Badan Litbang Kesehatan

Kartini AR (2012) Karakterisasi Molekular Padi Transgenik dengan Beberapa Metode Isolasi DNA. Skripsi. Departemen Biokimia. Fakultas
Matematika dan Ilmu Pengetahuan Alam Institut Pertanian Bogor, Bogor

Khanuja SPS, Shasany KA, Darokar S, Kumar (1999) Rapid Isolation of DNA from Dry and Fresh Samples of Plants Producing Large Amounts of Secondary Metabolites and Essential Oil. Plant Mol Biol Rep 17:74-74

Padmadi B (2009) Identifikasi sifat aroma tanaman padi menggunakan marka berbasis gen aromatik. Skripsi. Fakultas Matematika dan IImu Pengetahuan Alam, Institut Pertanian Bogor, Bogor

Royani JI (2012) Pengaruh Iradiasi Sinar Gamma Cobalt 60 Terhadap Perubahan Karakter Morfologi, Molekuler dan Senyawa Aktif Tanaman Sambiloto (Andrographis paniculata (Burm.f.) Wallich Ex Ness. Tesis. Sekolah Pasca Sarjana Institut Pertanian Bogor, Bogor

Sauer PM, Muller, Kang J (1998) Quantitation DNA. Qiagen News 2:2326

Sudewo B (2004) Tanaman Obat Populer Penggempur Aneka Penyakit. PT. Agromedia Pustaka. Jakarta.

Surzycki SJ (2000) Basic Techniques in Molecular Biology. Springer-Verlag Publisher 3-540-66678-8

Syahid SF (2007) Pertumbuhan, produksi, analisa mutu dan fitokimia keladi tikus (Thyponium flagelliforme) asal kultur kalus. Balai Penelitian Tanaman Obat dan Aromatik. (Belum dipublikasi)

Syahid SF (2008) Keragaman Morfologi Pertumbuhan, Produksi, Mutu dan Fitokimia Keladi Tikus (Typonium Flagelliforme Lodd.) Blume Asal Variasi Somaklonal. J Penelitian Tanaman Industri 14:113-118

Tel-zur N, Abbo S, Myslabodski D, Mizrahi Y (1999) Modified CTAB procedure for DNA isolation from epiphytic cacti of genera hylocereus and selenicereus (Cactaceae). Plant Mol Biol Rep 17:249-254

Weising $\mathrm{K}$, Nybom $\mathrm{H}$, Wolff $\mathrm{K}$, Meyer W (1995). DNA fingerprinting in plants and fungi. CRC Press. Boca Raton

Yuwono T (2009) Biologi Molekular. Erlangga, Jakarta 